\title{
Prevalence of Behavioral Problems in Adolescents in Social Vulnerability: Assessment from a Parental Perspective
}

\author{
Isabela Sousa Lemos Couto ${ }^{1}$ \\ Marina Monzani da Rocha ${ }^{2}$ (D) \\ Ana Cristina Botelho \\ Claudia Luísa Sena Gomes de Souza ${ }^{1}$ \\ Dagoberto Bonavides de Oliveira ${ }^{1}$ \\ Irismar Reis de Oliveira
}

\begin{abstract}
Although there are international data on the prevalence of behavioral problems through childhood/adolescence, there is still a need to explore emotional/behavioral problems experienced by Brazilian adolescents, especially in situations of extreme social problems or social vulnerability (SV). This is an observational, cross-sectional study, carried out with a convenience sample, to describe emotional/behavioral problems of adolescents living in a high SV scenario in the city of Salvador-BA, from their parents or guardians' point of view. Sociodemographic questionnaire and CBCL/6-18 were applied to a sample of 274 adolescents' parents/guardians. Data analysis found that $20.4 \%$ of the sample had problems in the clinical range for CBCL's Total Problems. Sociodemographic variables can impact behavioral problems in adolescence and need to be investigated. This study adds new data on child and youth psychopathologies at the national level and can promote preventive actions and referrals aimed at this population.
\end{abstract}

Keywords: behavior disorders, epidemiology, mental health, adolescents, social issues

\section{Prevalência de Problemas de Comportamento em Adolescentes em Situação de Vulnerabilidade Social: Avaliação a partir da Perspectiva dos Pais}

\begin{abstract}
Resumo: Mesmo diante de dados internacionais sobre prevalência de problemas de comportamento durante a infância/adolescência, ainda há necessidade de explorar problemas emocionais/comportamentais vivenciados pelos adolescentes brasileiros, especialmente em situações de altos problemas sociais ou de vulnerabilidade social (VS). Foi realizado estudo observacional, transversal, com amostra de conveniência, que teve por objetivo descrever os problemas emocionais/comportamentais apresentados por adolescentes que vivem em um contexto de alta VS na cidade de Salvador-BA, a partir do ponto de vista de seus pais ou responsáveis. Foram aplicados questionário sociodemográfico e CBCL/6-18 numa amostra de 274 pais/responsáveis pelos adolescentes. Análises dos dados obtidos indicaram que 20,4\% da amostra apresentaram problemas na faixa clínica para escala total do instrumento. Variáveis sociodemográficas podem influenciar os problemas de comportamento na adolescência, necessitando ser investigadas. Este estudo colabora com novos dados sobre psicopatologias infanto-juvenis em âmbito nacional, o que possibilita criar ações preventivas e encaminhamentos voltados para esta população.
\end{abstract}

Palavras-chave: distúrbios do comportamento, epidemiologia, saúde mental, adolescentes, problemas sociais

\section{Prevalencia de Problemas de Conducta en Adolescentes en Situación de Vulnerabilidad Social: Evaluación desde la Perspectiva de los Padres}

\begin{abstract}
Resumen: Aún cuando existan datos internacionales sobre la prevalencia de problemas de conducta durante la infancia/adolescencia, aún es necesario explorar los problemas emocionales/de conducta que experimentan los adolescentes brasileños, especialmente en contextos de alta vulnerabilidad social (VS). Se realizó un estudio observacional de conveniencia transversal para describir los problemas emocionales/conductuales presentados por adolescentes, de 11 a 17 años, que viven en un contexto de alta vulnerabilidad social en la ciudad de Salvador-BA, desde el punto de vista de los padres/tutores. Se aplicó un cuestionario sociodemográfico y el CBCL/6-18 a una muestra de 274 padres/tutores de adolescentes. El análisis de los datos indicó que el 20.4\% de la muestra tenía problemas en el rango clínico en la escala completa del instrumento. Las variables sociodemográficas pueden influir en los problemas de conducta en la adolescencia y deben investigarse. Este estudio colabora con nuevos datos sobre las psicopatologías infantiles y juveniles en todo el país, lo que permite crear acciones preventivas y referencias dirigidas a esa población.
\end{abstract}

Palabras clave: trastornos de la conducta, epidemiología, salud mental, adolescentes, problemas sociales

${ }^{1}$ Universidade Federal da Bahia, Salvador-BA, Brazil

${ }^{2}$ Universidade Presbiteriana Mackenzie, São Paulo-SP, Brazil

Article derived from the master's thesis of the first author under the supervision last author, defended in 2017, in the Programa de Pós-graduação em Processos Interativos dos Órgãos e Sistemas from Universidade Federal da Bahia.

Correspondence address: Isabela Sousa Lemos Couto. Universidade Federal da Bahia. Avenida Reitor Miguel Calmon, s/n, Canela, Salvador-BA, Brazil. CEP 40.231-300. E-mail: isabela.couto@ymail.com
Adolescence is historically portrayed as a chaotic phase of life, with moments of resistance and behavioral problems, as well as a universal stage of the development for all individuals (Habigzang, Diniz, \& Koller, 2014). The age group corresponding to this stage of life varies according to the source's definition. The Estatuto da Criança 
e do Adolescente (ECA) (Law no. 8,069, 1990), considered adolescence as the period of life that comprises the age of 12 to 18 years old; the World Health Organization (WHO) defined it as ages from 10 to 19 years. In this work, we include those aged from 11 to 17 years old.

In Brazil, ECA is the historic milestone of the children and adolescents' inclusion as subjects of law, in which the "right to freedom, respect and dignity as human beings in the course of development and as subjects of civil rights is expressed, the human and social rights guaranteed by the Constitution and by the laws "(Law no. 8,069, 1990, p. 13,564). Despite this acknowledgment, adolescence is a period of risk for vulnerability conditions, especially when we speak of adolescents within contexts of social inequality, with no guarantee of access to basic survival needs and, much less, to the conditions that would support the ideal development.

The condition of social problems, that is, the Social Vulnerability (SV) scenario of families in Brazil, is historically emphasized and remains current today (Stacciarini, 2013). According to the Instituto de Pesquisa Econômica e Aplicada (Costa \& Marguti, 2015), there are significant inequalities among Brazilian regions. Thus, scenarios of low vulnerability are found in municipalities in the South and Southeast of Brazil, while those of high vulnerability, in the North and Northeast, which indicates the severity of the problem of this studied group.

Some risk factors, such as poverty, low status of parents' occupation, low education, and lack of a support network, are considered negative conditions that can aggravate SV (Benatto, 2016). Young people and children who live in these poor circumstances of social inequalities are in SV condition. In this context, it is necessary to understand the vulnerability, as it encompasses several types of social loss, especially the weakening of affective bonds, of social belonging or related to some type of violence (Pereira, 2016), situations that can also prove to be motivating factors or causing behavioral problems in young adolescents, since children living in families with financial problems and vulnerable environments tend to have more problems with school performance and behavior (Ferreira \& Marturano, 2002).

It must be considered that the cycle of poverty prevails in the family, so that children who are exposed to several risk factors, such as poor diet, illnesses, low-quality education, turning into young adults with low wages, or without ever becoming employed, and who can establish families in the same condition (Ernst, Phillips, \& Duncan, 2013). Thus, the understanding of the difficulties experienced by adolescents must include a wide analysis of the context they live in.

Thus, several factors have been associated with behavioral problems, such as the high level of stress in the environment, low income, parental psychopathology in parents and other risk factors (Borsa, Souza, \& Bandeira, 2011; Matsukura, Fernandes, $\&$ Cid, 2014). These risk factors are commonly reflected as action, characteristic, experience, or episode that enhance or facilitate the occurrence of problems, or troubling consequences for the individual's social or psychological functioning.

Especially concerning socioeconomic factors, as discussed concerning SV, Assis, Avanci and Oliveira (2009) state that living in economic and social circumstances with a high level of precariousness, establishes a factor related to precarious social competence and the onset and development of behavioral problems in children. These results agree with other studies (Ferreira \& Marturano, 2002; Fonseca, Sena, Santos, Dias, \& Costa, 2013).

Pertain to the worldwide prevalence of mental and behavioral disorders and developmental disorders, Vinocur and Pereira (2011), according to the $\mathrm{WHO}$, pointed out rates between $10 \%$ and $20 \%$ in childhood and adolescence. These indicators are in line with Kieling et al. (2011) and Petresco et al. (2014) and were confirmed in a meta-analysis carried out in 2015 (Polanczyk, Salum, Sugaya, Caie, \& Rohde, 2015), which found the worldwide prevalence of mental disorders in children and adolescents at $13.4 \%$. Also, the prevalence of depressive symptoms is $7.72 \%$ in schoolchildren assessed in public schools in the city of Salvador (Bahia, Brazil), which shows the magnitude of the problem also at the national level (Couto, Reis, \& Oliveira, 2016).

The assessment of behavioral problems in children and adolescents is usually carried out through self-report questionnaires, or reports from parents and/or teachers, using standardized interviews or checklists. Some instruments with specific objectives are commonly used, among them, the Child Behavior Checklist (CBCL/6-18) (Achenbach \& Rescorla, 2001; Bordin et al., 2013), a tool used in this study and widely applied in assessing behavior problems in this age group.

In Brazil, currently, no prevalence studies are covering the whole country. However, local studies show similar prevalence data. An epidemiological study carried out in southern Brazil with a sample of 634 children (four years of age), using the $\mathrm{CBCL}$, revealed a prevalence of clinical and borderline scores in $24 \%$ of the sample, not separating gender differences (Anselmi, Piccinini, Barros, \& Lopes, 2004). Paula, Duarte and Bordin (2007) found very similar rates (24.6\%), evaluating children and adolescents with CBCL from a probabilistic sample of conglomerates including all eligible households in a low-income neighborhood in greater São Paulo. Also, with the use of CBCL, Predebon and Wagner (2005) evaluated 523 adolescents (15 to 18 years old), in the city of Porto Alegre - Rio Grande do Sul (RS) and revealed a clinical prevalence of $22 \%$.

Higher rates were found in the state of RS in the study by Borsa et al. (2011), in which 39.3\% of the studied sample had scores in the clinical range of the total CBCL behavior problem scale. Vitolo, Fleitlich-Bilyk, Goodman and Bordin (2005), found problems in the clinical range for $35.2 \%$ of the sample studied in the city of Taubaté, in the state of São Paulo, evidencing the severity of being exposed to SV.

Lopes et al. (2016), in a child and adolescent mental health analysis and survey, with high representativeness nationwide (in municipalities with more than 100,000 inhabitants) - another important epidemiological survey conducted in Brazil -, evaluated data on adolescents' mental morbidity and indicated the prevalence of common mental disorders in $30.0 \%$ of the sample of students analyzed. The research revealed differences according to the age group, sex, and region of the country, being the girls aged between 15 and 17 years in the North region the most affected and boys aged between 12 and 14 years, 
living in the Southeast, the least affected. The publications on the prevalence of mental health problems in childhood and adolescence highlight many international and some national studies. However, a significant discrepancy is found due to the distinct variables found in the analyzes, which points to the need for specific studies in different regions of Brazil to meet local demands. This becomes even more important when it involves young people in a high SV condition, since they are exposed to several risk factors and, as a result, they should be the target of diagnostic, preventive and therapeutic work. Thus, an observational, cross-sectional study was carried out, using a convenience sample, which aimed to describe the emotional/ behavioral problems of adolescents living in a scenario of high SV in the city of Salvador-BA, from parents or guardians' point of view. It is hoped, with this information, to contribute to the mapping of the mental health demands of these young people and, with this, discuss the public policies necessary to care for the mental health of this population.

\section{Method}

This study is characterized as observational, cross-sectional, using a convenience sample for and is part of a larger research, entitled: "Study of the effectiveness of Group Trial-Based Cognitive Training (G-TBCT) in the prevention of anxiety and depression disorders in adolescents of municipal private and public schools in Salvador-BA: a randomized clinical trial".

It is relevant to highlight some characteristics of the neighborhood where the study was carried out. The region of Salvador-BA is characterized by an important illiteracy rate or low schooling for a large part of its residents (Companhia de Desenvolvimento Urbano do Estado da Bahia [CONDER], 2016). Also, the high rate of poverty, social inequality, drug dealing and crime in this region stands out, which is strongly related to the $\mathrm{SV}$ issues.

\section{Participants}

All those responsible (total of 363) for adolescents, aged between 11 and 17 years, enrolled between from the sixth to the ninth grades of elementary school, students from the municipal education system schools in the city of Salvador - BA, were invited to participate in this study. All of them agreed to participate in the study. However, 89 gave incomplete responses, which resulted in a total of 274 , with a sample loss of (24.5\%). The inclusion criterion was to be responsible for a student who attended classes from the sixth to the ninth grade of the institution chosen by convenience. The exclusion criterion, on the other hand, was the incomplete or inadequate report of the assessment instruments.

\section{Instruments}

Sociodemographic Questionnaire (QSD). This instrument aimed to collect information related to students, such as age, sex, family socioeconomic status. This information allowed the sample characterization. The questionnaire, designed to carry out the research, presented 10 objective questions and addressed to the students' parents.

Child Behavior Checklist (Achenbach \& Rescorla, 2001). An assessment form aimed at parents/guardians to provide data on behavioral, emotional and social problems of their child/adolescent aged 6 to 18 years old. It presents 118 problem items that describre the most common chil and adolescent psychopathological symptoms, which are grouped in internalizing and externalizing problems. Scores are calculated by the sum of items in each scale and are cathegorized as being in the clinical, borderline, or normal range (Bordin et al., 2013).

In Brazil, studies have already been carried out to validate this instrument (Bordin et al., 2013). The first one indicated a good correlation between the problems identified using the CBCL and the assessment carried out by a specialist psychiatrist (Bordin, Mari, \& Caeiro, 1995). Moreover, good levels of reliability and adequacy of their factorial structure were found for a sample of Brazilian children (Rocha et al., 2013).

\section{Procedure}

Data collection. After the approval by the ethics committee on research with human beings, authorization was obtained from the Secretaria de Educação do Município de Salvador-BA and from the direction of the municipal school. With the students' consent, data collection was scheduled by telephone contact with parents or guardians, and carried out in a single meeting, in regular class hours, after prior agreement with the direction, in which both instruments were filled out. All were accordingly informed of voluntary and unpaid participation, and may even leave at any time, without harm. Furthermore, the researchers participating in the data collection, who were graduate students, were properly trained and qualified to apply the instruments used.

Data analysis. The CBCL's data were processed using the ADM 9.1 Assessment Data Manager program, created for this purpose. First, descriptive analyzes were carried out to detect the frequency that the behavior problems occurred in the sample. It was decided to consider borderline scores as clinical scores, in line with the recommendation of Achenbach and Rescorla (2001) for research with CBCL/6-18. The data were presented by sample stratification, considering the variables sex (male x female) and age group (11 to 14 years x 15 to 17 years). Inferential statistical analyzes were carried out to verify whether there was variation by sex or age of the adolescents. The $t$-test was used to compare means, while the chi-square test was used to verify differences in the scores' distribution in the normal and clinical ranges of the CBCL. All analyzes were performed using the SPSS 19.0 program (Statistical Package for Social Sciences - Version 19.0).

\section{Ethical Considerations}

This study was approved by the Human Research Ethics Committee (CEPSH) of Maternidade Climério de Oliveira Universidade Federal da Bahia (UFBA), with the Sanatório 
São Paulo as a proposing institution, with a Certificate of Presentation for Ethical Appreciation - CAAE - no.: 42264315.0.0000.5543.

\section{Results}

\section{Characteristics of the sample under study}

As can be observed in Table 1, most participants were responsible for male adolescents $(53.3 \%)$. The most prevalent age group was 11 to 14 years $(74.8 \%)$, and the average age was 13.32 years $(S D=1.55$ years). It is worth noting the presence of young people aged $16(6.6 \%)$ and 17 years $(2.2 \%)$, ages that are not expected for elementary school students. Regarding ethnicity, most parents reported that their child was black $(47.8 \%)$, followed by mixedrace $(35.8 \%)$, white $(8.0 \%)$, yellow $(4.4 \%)$ and indigenous (4.0\%). Regarding consumer goods, most families did not have a car $(70.1 \%)$, there was only one computer in the house (54.4\%) and $15.0 \%$ of the adolescents did not have their own bed, showing the SV of the sample.

Table 1

Sociodemographic data of the sample

\begin{tabular}{|c|c|c|}
\hline & $N$ & $\%$ \\
\hline \multicolumn{3}{|l|}{$\operatorname{Sex}$} \\
\hline Female & 128 & $46.7 \%$ \\
\hline Male & 146 & $53.3 \%$ \\
\hline \multicolumn{3}{|c|}{ Age $-M=13.32$ (1.55) years } \\
\hline 11 to 14 years & 205 & $74.8 \%$ \\
\hline 15 to 17 years & 69 & $25.2 \%$ \\
\hline \multicolumn{3}{|l|}{ School grade } \\
\hline $6^{\text {th }}$ & 98 & $35.9 \%$ \\
\hline $7^{\text {th }}$ & 71 & $26.0 \%$ \\
\hline $8^{\text {th }}$ & 45 & $16.5 \%$ \\
\hline $9^{\text {th }}$ & 59 & $21.6 \%$ \\
\hline \multicolumn{3}{|l|}{ Race } \\
\hline Black & 131 & $47.8 \%$ \\
\hline Mixed-race & 98 & $35.8 \%$ \\
\hline White & 22 & $8.0 \%$ \\
\hline Yellow & 12 & $4.4 \%$ \\
\hline Indigenous & 11 & $4.0 \%$ \\
\hline \multicolumn{3}{|l|}{ Total of cars } \\
\hline 0 & 192 & $70.1 \%$ \\
\hline 1 & 76 & $27.7 \%$ \\
\hline 2 & 6 & $2.2 \%$ \\
\hline \multicolumn{3}{|l|}{ Total of computers } \\
\hline 0 & 45 & $16.4 \%$ \\
\hline 1 & 149 & $54.4 \%$ \\
\hline 2 or more & 80 & $29.2 \%$ \\
\hline \multicolumn{3}{|c|}{ Does the teenager have his own bed? } \\
\hline Yes & 233 & $85.0 \%$ \\
\hline No & 41 & $15.0 \%$ \\
\hline
\end{tabular}

\section{Prevalence of Behavioral Problems}

Table 2 shows the frequency of adolescents with scores in the clinical range on the CBCL/6-18 behavior problem scales. It is important to mention that the same adolescent can achieve scores in the clinical range in more than one subscale of the instrument (Achenbach \& Rescorla, 2001).

Table 2

Percentage of adolescents with scores in the CBCL/6-18 clinical range

\begin{tabular}{lcc}
\hline \multicolumn{1}{c}{ CBCL Scale } & $N$ & $\%$ \\
\hline Anxious/Depressed & 28 & $10.2 \%$ \\
Withdrawal/Depression & 9 & $3.3 \%$ \\
Somatic Problems & 29 & $10.6 \%$ \\
Social Problems & 26 & $9.5 \%$ \\
Thought Problems & 26 & $9.5 \%$ \\
Attention Problems & 16 & $5.8 \%$ \\
Rule-Breaking Behavior & 4 & $1.5 \%$ \\
Aggressive Behavior & 26 & $9.5 \%$ \\
Internalizing Problems & 45 & $16.4 \%$ \\
Externalizing Problems & 42 & $15.3 \%$ \\
Total Problems & 56 & $20.4 \%$ \\
DSM - Affective Problems & 36 & $13.1 \%$ \\
DSM - Anxiety Problems & 27 & $9.9 \%$ \\
DSM - Somatic Problems & 23 & $8.4 \%$ \\
DSM - Attention Deficit/Hyperactivity & 17 & $6.2 \%$ \\
Problems & 25 & $9.1 \%$ \\
DSM - Oppositional Defiant Problems & 15 & $5.5 \%$ \\
DSM - Conduct Problems & &
\end{tabular}

An equivalent percentage of adolescents obtained scores in the clinical range for externalizing (15.3\%) and internalizing (16.4\%) problems. Also, a total of 87 adolescents (31.8\%) achieved clinical scores on both scales. In the total scale, $20.4 \%$ of the adolescents in the sample reached scores in the clinical range.

Considering the $\mathrm{CBCL} / 6-18$ behavior problems syndromes scales, Somatic Complaints and Anxious/ Depressed were the ones with the highest prevalence of scores in the clinical range, with $10.6 \%$ and $10.2 \%$, respectively. It should be highlighted the low number of adolescents with clinical scores on the Rule-Breaking scale: only 4 parents (1.5\%) indicated problems in intensity/ frequency equivalent to the clinical range. Analyzing the results from the DSM-oriented scales, Affective and Anxiety Problems were the most prevalent difficulties (13.1\% and $9.9 \%$, respectively).

\section{Differences by sex}

The comparison of the mean score obtained by boys and girls on the CBCL/6-18 scales showed little differences, with the Rule-Breaking scale being the only one for which the $t$-test indicated a statistically significant difference. On this scale, boys scored higher than girls (Table 3). 
Table 3

Differences by sex - Comparison of mean scores and percentage of adolescents with scores in the clinical range

\begin{tabular}{|c|c|c|c|c|c|c|c|c|}
\hline & \multicolumn{4}{|c|}{ Comparison of means - score } & \multicolumn{4}{|c|}{ Cases with scores in the clinical range } \\
\hline & $\begin{array}{c}\text { Girls } \\
M(\mathrm{~S} D)\end{array}$ & $\begin{array}{c}\text { Boys } \\
M(\mathrm{~S} D) \\
\end{array}$ & $t$ & $p$ & $\begin{array}{c}\text { Girls } \\
N(\%)\end{array}$ & $\begin{array}{c}\text { Boys } \\
N(\%)\end{array}$ & $\mathrm{X}^{2}$ & $p$ \\
\hline Anxious/Depressed & $5.03(4.03)$ & $5.14(3.98)$ & -0.218 & 0.827 & $9(7 \%)$ & $19(13 \%)$ & 2.661 & 0.075 \\
\hline Withdrawal/Depression & $3.18(2.63)$ & $3.34(3.02)$ & -0.430 & 0.668 & $3(2.3 \%)$ & $6(4.1 \%)$ & 0.669 & 0.320 \\
\hline Somatic Problems & $3.34(3.01)$ & $3.07(3.52)$ & 0.671 & 0.503 & $11(8.6 \%)$ & $18(12.3 \%)$ & 1.005 & 0.211 \\
\hline Social Problems & $3.75(2.82)$ & $3.67(3.25)$ & 0.213 & 0.832 & $12(9.4 \%)$ & $14(9.6 \%)$ & 0.004 & 0.559 \\
\hline Thought Problems & $2.16(2.57)$ & $2.36(2.66)$ & -.0630 & 0.529 & $9(7 \%)$ & $17(11.6 \%)$ & 1.690 & 0.137 \\
\hline Attention Problems & $4.93(4.01)$ & $5.60(4.59)$ & -1.283 & 0.201 & $7(5.5 \%)$ & $9(6.2 \%)$ & 0.060 & 0.507 \\
\hline Rule-Breaking Behavior & $2.44(2.60)$ & $3.09(2.91)$ & -1.957 & 0.050 & $4(3.1 \%)$ & $0(0 \%)$ & 4.630 & 0.046 \\
\hline Aggressive Behavior & $7.28(6.11)$ & $7.83(6.15)$ & -0.738 & 0.461 & $16(12.5 \%)$ & $10(6.8 \%)$ & 2.536 & 0.083 \\
\hline Internalizing Problems & $11.56(7.96)$ & $11.54(8.90)$ & 0.013 & 0.989 & $15(11.7 \%)$ & $30(20.5 \%)$ & 3.874 & 0.035 \\
\hline Externalizing Problems & $9.72(8.32)$ & $10.92(8.52)$ & -1.175 & 0.241 & $19(14.8 \%)$ & $23(15.8 \%)$ & 0.043 & 0.485 \\
\hline Total Problems & $36.29(24.08)$ & $38.74(26.64)$ & -0.794 & 0.428 & $22(17.2 \%)$ & $34(23.3 \%)$ & 1.561 & 0.136 \\
\hline DSM - Affective Problems & $4.02(3.77)$ & $4.04(3.60)$ & -0.057 & 0.954 & $15(11.7 \%)$ & $21(14.4 \%)$ & 0.424 & 0.319 \\
\hline DSM - Anxiety Problems & $2.77(2.24)$ & $2.82(2.35)$ & -0.150 & 0.881 & $9(7 \%)$ & $18(12.3 \%)$ & 2.155 & 0.102 \\
\hline DSM - Somatic Problems & $1.65(2.07)$ & $1.50(2.21)$ & 0.571 & 0.568 & $7(5.5 \%)$ & $16(11 \%)$ & 2.674 & 0.077 \\
\hline DSM - Attention Deficit/Hyperactivity Problems & $4.27(3.38)$ & $4.42(3.35)$ & -0.372 & 0.711 & $6(4.7 \%)$ & $11(7.5 \%)$ & 0.950 & 0.236 \\
\hline DSM - Oppositional Defiant Problems & $2.77(2.36)$ & $3.05(2.56)$ & -0.941 & 0.347 & $10(7.8 \%)$ & $15(10.3 \%)$ & 0.498 & 0.311 \\
\hline DSM - Conduct Problems & $2.34(3.28)$ & $2.87(3.23)$ & -1.356 & 0.176 & $9(7 \%)$ & $6(4.1 \%)$ & 1.125 & 0.213 \\
\hline
\end{tabular}

Some differences were found concerning the percentage of adolescents who achieved clinical scores on the CBCL scales. Boys had higher rates, compared to girls, in the following scales: Internalizing Problems (20.5\% x 11.7\%); Anxious/Depressed (13\% x 7\%); Somatic complaints $(12.3 \% \times 8.6 \%)$; Thought Problems (11.6\% x 7\%) and Total Problems (23.3\% x 17.2\%). Moreover, they reached the clinical range on all DSM-oriented scales, except for DSM-Conduct Problems, in which the girls had clinical scores more frequently $(7 \% \times 4.1 \%)$. Girls also achieved clinical scores more frequently on the Rule-Breaking (3.1\% x $0 \%)$ and Aggressive Behavior (12.5\% x 6.8\%) scales. The difference by sex in the proportion of adolescents with scores in the clinical range was statistically significant only for the Internalizing Problem scale $(p=0.035)$ and for Rule-Breaking $(p=0.046)$, although there is a significant difference trend in the Anxious/Depressed ( $p=0.075)$, Aggressive Behavior $(p=0.083)$ and DSM-Somatic Problems $(p=0.077)$.

\section{Differences by Age Group}

Table 4 shows the data found according to the age group.

Table 4

Differences by age group - Comparison of mean scores and percentage of adolescents with scores in the clinical range

\begin{tabular}{|c|c|c|c|c|c|c|c|c|}
\hline & \multicolumn{4}{|c|}{ Comparison of means - score } & \multicolumn{4}{|c|}{ Cases with scores in the clinical range } \\
\hline & $\begin{array}{c}11 \text { to } 14 \\
\text { years } \\
M(D P)\end{array}$ & $\begin{array}{c}15 \text { to } 17 \\
\text { years } \\
M(D P)\end{array}$ & $t$ & $p$ & $\begin{array}{c}11 \text { to } 14 \\
\text { years } \\
N(\%)\end{array}$ & $\begin{array}{c}15 \text { to } 17 \\
\text { years } \\
N(\%)\end{array}$ & $\mathrm{X}^{2}$ & $p$ \\
\hline Anxious/Depressed & $5.20(4.02)$ & $4.74(3.92)$ & 0.837 & 0.403 & $22(10.7 \%)$ & $6(8.7 \%)$ & 0.233 & 0.412 \\
\hline Withdrawal/Depression & $3.03(2.62)$ & $3.97(3.34)$ & -2.402 & 0.036 & $5(2.4 \%)$ & $4(5.8 \%)$ & 1.833 & 0.166 \\
\hline Somatic Problems & $3.15(3.26)$ & $3.31(3.40)$ & -0.366 & 0.715 & $22(10.7 \%)$ & $7(10.1 \%)$ & 0.019 & 0.547 \\
\hline Social Problems & $3.74(3.08)$ & $3.61(2.98)$ & 0.312 & 0.755 & $18(8.8 \%)$ & $8(11.6 \%)$ & 0.476 & 0.317 \\
\hline Thought Problems & $2.27(2.67)$ & $2.23(2.47)$ & 0.113 & 0.910 & $22(10.7 \%)$ & $4(5.8 \%)$ & 1.464 & 0.166 \\
\hline Attention Problems & $5.17(4.30)$ & $5.65(4.47)$ & -0.805 & 0.422 & $10(4.9 \%)$ & $6(8.7 \%)$ & 1.368 & 0.188 \\
\hline Rule-Breaking Behavior & $2.60(2.67)$ & $3.36(2.99)$ & -2.003 & 0.046 & $2(1 \%)$ & $2(2.9 \%)$ & 1.327 & 0.264 \\
\hline Aggressive Behavior & $7.60(6.10)$ & $7.49(6.99)$ & 0.126 & 0.900 & $22(10.7 \%)$ & $4(5.8 \%)$ & 1.464 & 0.166 \\
\hline
\end{tabular}

Continued... 
Table 4

Continuation

\begin{tabular}{|c|c|c|c|c|c|c|c|c|}
\hline & \multicolumn{4}{|c|}{ Comparison of means - score } & \multicolumn{4}{|c|}{ Cases with scores in the clinical range } \\
\hline & $\begin{array}{l}11 \text { to } 14 \\
\text { years } \\
M(D P)\end{array}$ & $\begin{array}{l}15 \text { to } 17 \\
\text { years } \\
M(D P)\end{array}$ & $t$ & $p$ & $\begin{array}{l}11 \text { to } 14 \\
\text { years } \\
N(\%)\end{array}$ & $\begin{array}{c}15 \text { to } 17 \\
\text { years } \\
N(\%)\end{array}$ & $X^{2}$ & $p$ \\
\hline Internalizing Problems & $11.38(8.33)$ & $12.03(8.89)$ & -0.546 & 0.586 & $33(16.1 \%)$ & $12(17.4 \%)$ & 0.063 & 0.467 \\
\hline Externalizing Problems & $10.19(8.34)$ & $10.86(8.72)$ & -0.566 & 0.572 & $30(14.6 \%)$ & $12(17.4 \%)$ & 0.302 & 0.354 \\
\hline Total Problems & $37.29(25.02)$ & $38.52(26.89)$ & -0.349 & 0.727 & $40(19.5 \%)$ & $16(23.2 \%)$ & 0.429 & 0.310 \\
\hline DSM - Affective Problems & $3.91(3.51)$ & $4.39(4.12)$ & -0.947 & 0.345 & $26(12.7 \%)$ & $10(14.5 \%)$ & 0.148 & 0.419 \\
\hline DSM - Anxiety Problems & $2.89(2.33)$ & $2.52(2.18)$ & -1.149 & 0.252 & $19(9.3 \%)$ & $8(11.6 \%)$ & 0.314 & 0.361 \\
\hline DSM - Somatic Problems & $1.52(2.14)$ & $1.72(2.15)$ & -0.695 & 0.488 & $17(8.3 \%)$ & $6(8.7 \%)$ & 0.011 & 0.544 \\
\hline DSM - Attention Deficit/Hyperactivity Problems & $4.40(3.37)$ & $4.29(3.32)$ & 0.432 & 0.666 & $13(6.3 \%)$ & $4(5.8 \%)$ & 0.026 & 0.567 \\
\hline DSM - Oppositional Defiant Problems & $2.91(2.42)$ & $2.97(2.63)$ & -0.185 & 0.853 & $18(8.8 \%)$ & $7(10.1 \%)$ & 0.116 & 0.448 \\
\hline DSM - Conduct Problems & $2.48(3.21)$ & $3.04(3.38)$ & -1.249 & 0.213 & $10(4.9 \%)$ & $5(7.2 \%)$ & 0.314 & 0.361 \\
\hline
\end{tabular}

Although there are some differences in the behavior problems reported by parents of the youngest (11 to 14 years old) and older (15 to 17 years old), the comparison of the means showed a statistically significant difference only for scores of the withdrawal/depression scales ( $p=0.036)$ and Rule-Breaking $(p=0.046)$. In both, the score of the olders was higher. No difference was found in the percentage of cases that reached the clinical range in the scales according to the age group.

\section{Discussion}

Aimed at understanding the emotional and behavioral difficulties presented by adolescents in an SV condition, according to their parents/guardians' point of view, the present study found the majority of scores in the clinical range for Somatic Complaints in $10.6 \%$ of the sample, followed by $10.2 \%$ problems related to Anxiety and Depression, which corroborates with the specialized literature (Couto et al., 2016). Other important prevalences were social problems, thought problems and aggressive behavior (9.5\% of the adolescents in the sample had clinical scores for these subscales). These data are in line, although to some extent, with other important studies (Borsa et al., 2011; Lopes et al., 2016), which pointed out the most prevalent problems related to Anxious/Depressed, with Thought Problems and Aggressive Behavior.

It is also observed that the prevalence of externalizing and internalizing problems was numerically equivalent, with $16.4 \%$ of adolescents reaching the clinical range for internalizing problems and $15.3 \%$ for externalizing problems. In the study by Fidalgo et al. (2018), in which the DSM-IV diagnostic criteria were used, violent experiences and low socioeconomic levels were associated with the presence of internalizing and externalizing problems. Thus, it is understood that the SV scenario does not seem to be associated with a specific type of problem, but rather with the existence of emotional and behavioral problems. The prevalence found in the present study are similar to those by Borsa et al. (2011), in working with children from Rio Grande do Sul, and Hess and Falcke (2013), in a systematic literature review (national and international data, aimed at internalizing problems in adolescents).

Concerning the Total Problems scale, $20.4 \%$ of the adolescents in the sample had problems in the clinical range ( $23.3 \%$ for boys and $17.2 \%$ for girls). In general, it is a high prevalence of behavior problems when compared to world data (Polanczyk et al., 2015), which is also in agreement with other studies carried out in Brazil (Borsa et al., 2011; Ferreira \& Marturano, 2002; Lopes et al., 2016).

Regarding sex differences, although girls reach the clinical range less frequently than boys for the Total Problems scale $(17.2 \% \times 23.3 \%)$, as well as in most CBCL/6-18 scales, they reached clinical scores more frequently on the Rule-Breaking (3.1\% x 0\%), Aggressive Behavior $(12.5 \% \times 6.8 \%)$ and DSM-Conduct Problems (7\% x 4, 1\%), which is in line with the data presented by other authors (Alarcón Parco \& Bárrig Jó, 2015; Borsa et al., 2011; Lopes et al., 2016). On the other hand, our data differ from those found by Machado et al., (2014) and Rescorla et al. (2007). Such data may be related to the place where the adolescents who participated in this study live and/or study, which is characterized as an area with a high rate of violence and significant socioeconomic inequality, which can be characterized as risk factors for the onset of certain behavior problems (Assis et al., 2009; Matsukura et al., 2014). In this sense, new studies must investigate the prevalence of problems considering the SV variable, especially when we consider that the existence of risk factors in the family, including exposure to poverty, psychiatric disorders among family members and domestic violence, is associated in the literature with higher frequency of emotional/behavioral problems (Fatori, Bordin, Curto, \& Paula, 2013; Fidalgo et al., 2018). 
Furthermore, it is important to consider these variables to also understand the higher frequency of boys with scores in the clinical range for Internalizing Problems Scale $(20.5 \% \times 11.7 \%)$, considering that international studies point that such issues are more frequent among adolescent girls (Bordin et al., 2013; Lopes et al., 2016; Rescorla et al., 2007). It is also necessary to highlight that the relationship between sex and behavior problems (internalizing and externalizing) is also not a consensus in the specific literature, according to the data exposed and other studies (Borsa et al., 2011).

The little difference in the problems pointed out by the parents of the youngest and oldest adolescents is more consensual in the literature than the questions related to differences by sex, the result found in the present study, similar to that found by the authors of CBCL/6-18 in the validation study (Achenbach \& Rescorla, 2001). Even so, it should be considered that in a study carried out using data collected from guardians of children and adolescents from 31 societies, the prevalence of problems on the CBCL Total Scale was higher among the older ones (Rescorla et al., 2007), as well as in the study by Lopes et al. (2016), in which older girls had the highest signs of common mental disorders.

However, the results found should be considered in the light of the study's limitations, which include the difficulty for time for availability of some parents or guardians to respond to the research assessment instruments, which was reflected in a sample loss of $24.5 \%$. Also, no instruments were adopted to measure the level of SV in the sample, which was assumed upon the school location and the limited access to declared consumer goods.

The reduced participation of older adolescents, since the study was carried out with elementary school students, without including those who attend high school, is also a limiting element. A larger sample, including older youth, provides a more expressive dimension of the magnitude of emotional/behavioral problems experienced by adolescents living in an SV condition in the region under study. Moreover, it should be considered that the present study used only the parent/guardian as an informant, which can be a limitation as the adolescent could also contribute with his/her view of the given difficulties.

The data found in the present study confirm the findings evidenced in the literature, which indicate a high prevalence of behavioral problems in the Brazilian children and youth population (Anselmi et al., 2004; Borsa et al., 2011; Lopes et al., 2016), as well as the association of these problems with SV (Fatori et al., 2013; Fidalgo et al., 2018). Besides, there are also differences when it comes to the prevalence of certain behavior problems concerning sex and the little difference varying on the age range of the adolescents assessed (Achenbach \& Rescorla, 2001).

Finally, our findings can contribute to the understanding of the patterns of behavioral/emotional problems in adolescentes of both sexes, age groups, and in the presence of SV. However, it is worth noting the need for new research and studies in this area, to favor the development of actions aimed at the adolescent's life context, aiming at reducing these behavior problems and promoting health and improving quality of life of children and adolescents, including those in the subgroups at higher risk.

\section{References}

Achenbach, T. M., \& Rescorla, L. A. (2001). Manual for the ASEBA school-age forms \& profiles. Burlington, VT: University of Vermont, Research Center for Children, Youth, \& Families.

Alarcón Parco, D., \& Bárrig Jó, P. S. (2015). Conductas internalizantes $\mathrm{y}$ externalizantes en adolescentes [Internalizing and externalizing behavior in adolescents]. Liberabit, 21(2), 253-259. Retrieved from http://www. scielo.org.pe/pdf/liber/v2 $\ln 2 / \mathrm{a} 08 \mathrm{v} 21 \mathrm{n} 2 . \mathrm{pdf}$

Anselmi, L., Piccinini, C. A., Barros, F. C., \& Lopes, R. S. (2004). Psychosocial determinants of behaviour problems in Brazilian preschool children. Journal of Child Psychology and Psychiatry, 45(4), 779-788. doi:10.1111/j.1469-7610.2004.00271.x

Assis, S. G., Avanci, J. Q., \& Oliveira, R. V. C. (2009). Socioeconomic inequalities and child mental health. Revista de Saúde Pública, 43(Suppl. 1), 92-100. doi:10.1590/S0034-89102009000800014

Benatto, M. E. C. (2016). A vulnerabilidade social da escola pública e a formação dos professores do $6^{\circ}$ ano do ensino fundamental [The social vulnerability of public schools and the education of 6th grade teachers] (Vol. 2: Cadernos PDE). Curitiba, PR: Universidade Tecnológica Federal do Paraná. Retrieved from http:// www.diaadiaeducacao.pr.gov.br/portals/cadernospde/ pdebusca/producoes_pde/2016/2016_pdp_ped_utfpr_ maristelaelisabetecosmobenatto.pdf

Bordin, I. A., Rocha, M. M., Paula, C. S., Teixeira, M. C. T. V., Achenbach, T. M., Rescorla, L. A., \& Silvares, E. F. M. (2013). Child Behavior Checklist (CBCL), Youth Self-Report (YSR) and Teacher's Report Form (TRF): An overview of the development of the original and Brazilian versions. Cadernos de Saúde Pública, 29(1), 13-28. doi:10.1590/S0102-311X2013000100004

Bordin, I. A. S., Mari, J. J., \& Caeiro, M. F. (1995). Validação da versão brasileira do Child Behavior Checklist (CBCL): Dados preliminares [Validation of the Brazilian version of the Child Behavior Checklist (CBCL): Preliminary data]. Revista ABP-APAL, 17(2), 55-66. Retrieved from https://www.researchgate.net/ publication/285968522_Validation_of_the_Brazilian version_of_the_Child_Behavior_Checklist_CBCL/ link/59f8c278a6fdcc075ec99697/download 
Borsa, J. C., Souza, D. S., \& Bandeira, D. R. (2011). Prevalência dos problemas de comportamento em uma amostra de crianças do Rio Grande do Sul [Prevalence of behavior problems in a sample of children from Rio Grande do Sul]. Psicologia: Teoria Prática, 13(2), 15-29.

Companhia de Desenvolvimento Urbano do Estado da Bahia. Sistema de Informações Geográficas Urbanas. (2016). Painel de informações: Dados socioeconômicos do municipio de Salvador por bairros e prefeiturasbairro [Information panel: Socioeconomic data of the municipality of Salvador by neighborhoods and prefectures-neighborhood]. (5a ed.). Salvador, BA: CONDER/INFORMS.

Costa, M. A., \& Marguti, B. O. (Eds.). (2015). Atlas da vulnerabilidade social nos municipios brasileiros [Atlas of social vulnerability in Brazilian municipalities]. Brasília, DF: IPEA. Retrieved from http://ivs.ipea.gov. br/images/publicacoes/Ivs/publicacao_atlas_ivs.pdf

Couto, I. S. L., Reis, D. M. L., \& Oliveira, I. R. (2016). Prevalência de sintomas de depressão em estudantes de 11 a 17 anos da rede pública de ensino de Salvador [Prevalence of symptoms of depression in students aged 11 to 17 years of public school in Salvador]. Revista de Ciências Médicas e Biológicas, 15(3), 370-374. doi:10.9771/cmbio.v15i3.18205

Ernst, K. C., Phillips, B. S., \& Duncan, B. D. (2013). Slums are not places for children to live: Vulnerabilities, health outcomes, and possible interventions. Advances in Pediatrics, 60(1), 53-87. doi:10.1016/j.yapd.2013.04.005

Fatori, D., Bordin, I. A., Curto, B. M., \& Paula, C. S. (2013). Influence of psychosocial risk factors on the trajectory of mental health problems from childhood to adolescence: A longitudinal study. BMC Psychiatry, 13, 31. doi:10.1186/1471-244X-13-31

Ferreira, M. C. T., \& Marturano, E. M. (2002). Ambiente familiar e os problemas do comportamento apresentados por crianças com baixo desempenho escolar [Home environment and behavior problems presented by school underachieving children]. Psicologia: Reflexão e Crítica, 15(1), 35-44. doi:10.1590/S0102-79722002000100005

Fidalgo, T. M., Sanchez, Z. M., Caetano, S. C., Andreoni, S., Sanudo, A., Chen, Q., \& Martins, S. S. (2018). Exposure to violence: Associations with psychiatric disorders in Brazilian youth. Brazilian Journal of Psychiatry, 40(3), 277-283. doi:10.1590/1516-4446-2016-2122

Fonseca, F. F., Sena, R. K. R., Santos, R. L. A., Dias, O. V., \& Costa, S. M. (2013). As vulnerabilidades na infância e adolescência e as políticas públicas brasileiras de intervenção [The vulnerabilities in childhood and adolescence and the Brazilian public policy intervention]. Revista Paulista de Pediatria, 31(2), 258264. doi:10.1590/S0103-05822013000200019
Habigzang, L. F., Diniz, E., \& Koller, S. H. (2014). Trabalhando com adolescentes: Teoria e intervenção psicológica [Working with adolescents: Theory and psychological intervention]. Porto Alegre, RS: Artmed.

Hess, A. R. B., \& Falcke, D. (2013). Sintomas internalizantes na adolescência e as relações familiares: Uma revisão sistemática da literatura [Internalizing symptoms in adolescence and family relationships: A systematic literature review]. Psico-USF, 18(2), 263-276. doi:10.1590/S1413-82712013000200010

Kieling, C., Baker-Henningham, H., Belfer, M., Conti, G., Ertem, I., Omigbodun, O., ... Rahman, A. (2011). Child and adolescent mental health worldwide: Evidence for action. The Lancet, 378(9801), 1515-1525. doi:10.1016/ S0140-6736(11)60827-1

Lei No. 8.069, de 13 de julho de 1990. (1990, 16 de julho). Dispõe sobre o Estatuto da Criança e do Adolescente e dá outras providências [Provides for the Statute of the Child and Adolescent and makes other provisions]. Diário Oficial da União, seção 1.

Lopes, C. S., Abreu, G. A., Santos, D. F., Menezes, P. R., Carvalho, K. M. B., Cunha, C. F., ... Szklo, M. (2016). ERICA: Prevalence of common mental disorders in Brazilianadolescents. Revistade Saúde Pública, 50(Suppl. 1), 1s-9s. doi:10.1590/S01518-8787.2016050006690

Matsukura, T. S., Fernandes, A. D. S. A., \& Cid, M. F. B. (2014). Saúde mental infantil em contextos de desvantagem socioeconômica: Fatores de risco e proteção [Child mental health in socioeconomically disadvantaged contexts: Risk and protective factors]. Cadernos Brasileiros de Terapia Ocupacional, 22(2), 251-262. doi:10.4322/cto.2014.047

Machado, C. M., Luiz, A. M. A. G., Marques Filho, A. B., Miyazaki, M. C.O. S., Domingos, N.A. M., \& Cabrera, E. M. S. (2014). Ambulatório de psiquiatria infantil: Prevalência de transtornos mentais em crianças e adolescentes [Children's psychiatric outpatient clinic: Prevalence of mental disorders among children and adolescents]. Psicologia: Teoria e Prática, 16(2), 53-62. doi:10.15348/1980-6906

Paula, C. S., Duarte, C. S., \& Bordin, I. A. S. (2007). Prevalence of mental health problems in children and adolescents from the outskirts of Sao Paulo City: Treatment needs and service capacity evaluation. Revista Brasileira de Psiquiatria, 29(1), 11-17. doi:10.1590/ S1516-44462006005000012

Pereira, S. E. F. N. (2016). Crianças e adolescentes em contexto de vulnerabilidade social: Articulação de redes em situação de abandono ou afastamento do convívio familiar [Children and adolescents in the context of social vulnerability: Networking in situations of abandonment or withdrawal from family life]. Retrieved from http://acolhimentoemrede.org.br/site/wp-content/ uploads/2016/08/Artigo-sobre-a-REDE.pdf 
Petresco, S., Anselmi, L., Santos, I. S., Barros, A. J. D., Fleitlich-Bilyk, B., Barros, F. C., \& Matijasevich, A. (2014). Prevalence and comorbidity of psychiatric disorders among 6-year-old children: 2004 Pelotas Birth Cohort. Social Psychiatry and Psychiatric Epidemiology, 49(6), 975-983. doi:10.1007/s00127-014-0826-z

Polanczyk, G. V., Salum, G. A., Sugaya, L. S., Caye, A., \& Rohde, L. A. (2015). Annual research review: A metaanalysis of the worldwide prevalence of mental disorders in children and adolescents. Journal of Child Psychology and Psychiatry, 56(3), 345-365. doi:10.1111/jcpp.12381

Predebon, J. C., \& Wagner, A. (2005). Problemas de comportamento na adolescência: Configuração familiar e aspectos sociodemográficos [Behavioral problems in adolescence: Family configuration and sociodemographic aspects]. Práxis, 2(2), 1-11. Retrieved from https://www. researchgate.net/publication/238791320_problemas de_comportamento_na_adolescencia_configuracao_ familiar_e_aspectos_sociodemograficos

Rescorla, L. A., Achenbach, T. M., Ivanova, M. Y., Dumenci, L., Almqvist, F., Bilenberg, N., ... Verhulst, F. (2007). Epidemiological comparisons of problems and positive qualities reported by adolescents in 24 countries. Journal of Consulting and Clinical Psychology, 75(2), 351-358. doi:10.1037/0022-006X.75.2.351

Rocha, M. M., Rescorla, L. A., Emerich, D. R., Silvares, E. F. M., Borsa, J. C., Araújo, L. G. S., ... Assis, S. G. (2013). Behavioural/emotional problems in Brazilian children: Findings from parents' reports on the Child Behavior Checklist. Epidemiology and Psychiatric Sciences, 22(4), 329-338. doi:10.1017/S2045796012000637

Stacciarini, I. C. (2013). Características das famílias em vulnerabilidade social no Brasil e em Brasília: Desmembrando o cenário da pobreza e extrema pobreza [Characteristics of families in social vulnerability in Brazil and Brasilia: Breaking down the scenario of poverty and extreme poverty]. Comunicação \& Mercado, 2(5), 7-19. Retrieved from https://www.unigran.br/ dourados/mercado/paginas/arquivos/edicoes/5/1.pdf

Vinocur, E., \& Pereira, H. V. F. S. (2011). Avaliação dos transtornos de comportamento na infância [Evaluation of behavioral disorders in children]. Revista Hospital Universitário Pedro Ernesto, 10(Supl.2), 26-34. Retrieved from http://revista.hupe.uerj.br/?handler=artigo\&id=103

Vitolo, Y. L. C., Fleitlich-Bilyk, B., Goodman, R., \& Bordin, I. A. S. (2005). Crenças e atitudes educativas dos pais e problemas de saúde mental em escolares [Educational beliefs and attitudes of parents and mental health problems in schoolchildren]. Revista de Saúde Pública, 39(5), 716724. doi:10.1590/S0034-89102005000500004
Isabela Sousa Lemos Couto is a Master and Doctoral Student of the Programa de Pós-Graduação em Processos Interativos dos Órgãos e Sistemas at Universidade Federal da Bahia, Savador-BA, Brazil.

Marina Monzani da Rocha is an Assistant Professor of the Programa de Pós-Graduação em Distúrbios do Desenvolvimento at Universidade Presbiteriana Mackenzie, São Paulo-SP, Brazil.

Ana Cristina Botelho is a Master of the Programa de PósGraduação em Processos Interativos dos Órgãos e Sistemas at Universidade Federal da Bahia, Savador-BA, Brazil.

Claudia Luísa Sena Gomes de Souza is a Master of the Programa de Pós-Graduação em Processos Interativos dos Órgãos e Sistemas at Universidade Federal da Bahia, Savador-BA, Brazil.

Dagoberto Bonavides de Oliveira is a Master of the Programa de Pós-Graduação em Processos Interativos dos Órgãos e Sistemas at Universidade Federal da Bahia, Savador-BA, Brazil.

Irismar Reis de Oliveira is a Professor of the Programa de PósGraduação em Processos Interativos dos Órgãos e Sistemas at Universidade Federal da Bahia, Savador-BA, Brazil.

\section{Authors' Contribution:}

All authors made substantial contributions to the conception and design of this study, to data analysis and interpretation, and the manuscript revision and approval of the final version. All the authors assume public responsibility for content of the manuscript.

Received: Feb. 22, 2019

1st Revision: Aug. 20, 2019

2nd Revision: Nov. 08, 2019

Approved: Mar. 06, 2020

\section{How to cite this article:}

Couto, I. S. L., Rocha, M. M., Botelho, A. C., Souza, C. L. S. G., Oliveira, D. B., \& Oliveira, I. R. (2020). Prevalence of behavioral problems in adolescents in social vulnerability: Assessment from a parental perspective. Paidéia (Ribeirão Preto), 30, e3039.doi:https://doi.org/10.1590/1982-4327e3039 